\title{
Occupational Portrait of A Pandemic Workforce: Latin Americans in the Health and the Sales \& Services Sectors of Canada ${ }^{1}$
}

Fernando Mata

School of Sociological and Anthropological Studies, University of Ottawa

February 23, 2021

fmata@uottawa.ca

\section{Abstract}

Reflecting on present COVID-19 pandemic times in Canada and using both visible and ethnic ancestry information from the 2016 census, the author produced an occupational portrait of the Latin American workforce of the Health and Sales \& Services sectors of the country. The focus was on full-time, full-year workers, aged 25-64, who received employment income in 2015. The workforce in the Health and Sales \& Services sectors totaled 5.5 thousand and 24.3 thousand individuals respectively. The occupational portrait, which was developed based on the Canadian 2016 NOC occupational classification system, revealed an active participation of Latino workers in activities enhancing sanitary protection and the economic survival of the Canadian population. Women, and established and recent immigrants as well as those reporting Central American ethnic origins were found among those who most participated in the economic activities of the sectors. The most typical jobs performed by Latin American workers were as nursing aides in the Health sector and janitorial (males) and light or specialized cleaners (women) in the Sales \& Services sector. The nature of these jobs made them a high health-risk group and vulnerable one in pandemic times as they entail working in close proximity to other colleagues and the general public.

\subsection{Introduction}

During the present COVID-19 pandemic, the health and sales \& service occupational sectors have emerged as important occupational "backbones" in terms of Canada's sanitary protection and economic survival. The Health sector comprises jobs aimed at providing health care

\footnotetext{
I Paper to be presented to the CSA conference in the University of Alberta, June 2021. The authors would like to thank Statistics Canada for making available the data and their valuable support and guidance.
} 
services directly to patients, the general public and provide support to professional and technical staff in the health field. The Sales and Services sector consists of a wide range of occupations ranging from sales, and personal and protective services to those related to the hospitality and tourism industries. At present, workers in these two vital economic sectors face increased health risks as a result of having been deemed "key" or "essential" during the various phases of the pandemic (Fassani and Mazza, 2020).

Latin Americans have been steadily arriving to Canada in the last decades and integrating themselves into its workforce. According to Canadian immigration statistics, about 2.5 million permanent residents were admitted to Canada between 2007 and 2016 (IRCC, 2017). Colombia, Mexico, Brazil and Venezuela topped the list of citizenship countries from the Latin American region $(39.8,36.3,19.2$ and 12.2 thousand individuals). As push-related factors have become stronger, the number of refugee claimants from Latin America has substantially increased over the years. During 2003-2012, the number of refugee claimants from Mexico and Colombia totaled approximately 37.5 and 17.5 thousand. Other major citizenship countries of claimants were El Salvador, Honduras, Guatemala and Cuba (IRCC, 2017) .

What is the participation of Latin Americans in the Health and Sales \& Services occupational sectors of Canada's workforce? What variations may be observed by gender, immigrant status and period of residence? Are there any variations by ethnic ancestries? What are the usual types of jobs they are engaged in? How do the occupational patterns compare to other visible and non-visible minorities of Canada? Using identity markers collected by the 2016 Census data, the purpose of this report is to address these broad research questions by producing a brief occupational portrait of the Latin American workforce in Canada. The report is intended to inform public agencies about the vital role that this working segment is playing in terms of Canada's health protection and economic security during the pandemic period.

\subsection{Target Population and Data Sources}

The target population of the report comprises all Latin American adults aged 25-64 who worked 
full-time, full year and reported employment income in $2015 .{ }^{2}$ Visible minority and ethnic markers collected by the 2016 census are used in conjunction with the 2016 National Occupational Classification System (NOC 2016) to produce the socio-demographic profiles of the report. The visible minority marker refers to whether a person belongs to a visible minority group as defined by the Employment Equity Act which defines them as "persons, other than Aboriginal peoples, who are non-Caucasian in race or non-white in colour" (Statistics Canada, 2018, p.51). ${ }^{3}$ The visible minority population consists mainly of the following groups: South Asian, Chinese, Black, Filipino, Latin American, Arab, Southeast Asian, West Asian, Korean and Japanese. The ethnic origins marker refers to the reported ethnic or cultural origins of the person's ancestors, where an ancestor is defined as a person usually more distant than a grandparent (Statistics Canada, 2018, p.11). ${ }^{4}$

According to the NOC 2016 system, an 'occupation' refers to the kind of work performed in a job, a job being all the tasks carried out by a particular worker to complete his or her duties. The broad classificatory structure of the NOC 2016 for one digit codes comprises 10 broad occupational sectors ranging from managerial and business to resources and manufacturing (codes 0 to 9). The finer occupational classification for four digit codes of the system comprises 499 job types providing a greater detail on the tasks involved (see detail for these occupations within the two sectors examined in Appendix A).

\subsection{Latin American Immigration to Canada}

Latin American immigration to Canada represent a wide array of national, racial and cultural backgrounds who have entered the country either as permanent residents (economic, family and refugee classes) or as temporary workers. Canadian scholars have

\footnotetext{
2 The visible minority data is drawn from Census tables 53 available at https://www12.statcan.gc.ca/censusrecensement/2016. The ethnic origin data is drawn from a special census tabulations E02860 and EO3181, 2016 Census of Canada

${ }_{3}$ The visible minority population consists mainly of the following groups: South Asian, Chinese, Black, Filipino, Latin American, Arab, Southeast Asian, West Asian, Korean and Japanese Workers reporting mixed visible minority backgrounds are excluded from the analysis. Due to the lower counts for Japanese visible minorities these are not shown in tables or graphs.

4 The reader should note that, in the case of the Latin American working population, these two identity markers not necessarily match in terms of counts as many of ethnic Latin American workers in Canada do not report and/or are not classified as visible minorities in Canada.
} 
conceptualized the Latin American immigration to Canada as the product of five major immigrant waves and associated sub-waves which have reproduced themselves over time (Mata 1985; Garay, 2000; Veronis, 2010 ; Landolt, Bernhard and Goldring, 2011). The first four waves brought individuals with European ties during the 60's which were later followed in the 70's and 80's by immigrants from Andean, Southern Cone and Central America escaping violence, searching for economic opportunities and social mobility (Simmons, 1993). At present, Canada is witnessing the unfolding of a fifth "technological" or "professional" wave, led by mostly highly skilled individuals drawn from the STEM industries coming from countries such as Colombia, Mexico and Venezuela (Landolt, Bernhard and Goldring, 2011).

An examination of the historical ethnic immigrant inflows entering Canada between 1980 and 2016 revealed significant differences in the immigrant class mix between the recent fifth wave and preceding ones (see Mata, 2019). Here, a higher predominance of either economic immigrant class admissions and/or family class ones were observed compared to refugee ones which were characteristic of the fourth wave from countries such as El Salvador, Nicaragua and Guatemala. The steady inflows of Latin American immigrants to Canada in conjunction with natural increase of its population had contributed to an increase in the reporting of Spanish and Latin American ethnic origins in Canadian censuses. In 2016, the total census counts for all those who reported Spanish and various Latin American ethnic backgrounds either as single or multiple origins totaled 463.4 thousand and 373.8 thousand respectively. Between the 2006 and 2016 censuses, these two ethnic subpopulations experienced an increase in the order of $21 \%$ and $34 \%$ respectively. The actual size of the Latin American population in Canada is difficult to estimate and depends on the reported identity marker used by statistical agencies. Some estimates done in 2016 put this figure at around 640,000 but a later 2020 reclassification done based by Statistics Canada on the ethnic origin of parents produced a number of almost 1 million individuals (Oliveira, 2020).

\subsection{Latin Americans in the Health and Sales \& Services Workforce}

The Latin American workforce of the Health and Sales \& Services sectors totaled 5.5 and 
24.3 thousand individuals respectively. The male workforce totaled 1.2 and 12.6 thousand individuals and the female one 4.3 and 12.7 thousand respectively. Nine out of the combined workforce (91\%) were born outside Canada with equal proportions among males and females. In terms of educational levels, more than one in three workers $(34.2 \%)$ had achieved an education level equal to a university certificate bachelor level or above ( $36.2 \%$ among females and $32.7 \%$ among males). About one in three (31.2\%) had attained a level of a high school certificate or below.

4.1. Nationally, women are over-represented in the Sales \& Services sector, equally in the Health sector.

Table 1 displays the occupational sector distribution of Latin Americans in the 10 major occupational groups identified by the 2016 NOC. About $5.0 \%$ were engaged in Health sector related jobs while $21.9 \%$ in Sales \& Services sector jobs, the latter percentage being higher compared to the overall for the rest of visible minorities (19.5\%) and non-visible minorities as well (15.1\%). Latin American women were 3.9 times more likely than Latin American men to be engaged in the Sales \& Services occupations, and 1.3 times more likely when compared to men with respect to the health sector. The Latin American participation of women in this sector was slightly higher compared to that of their rest of visible minority and non-visible minority counterparts ( $25.5 \%$ to $21.7 \%$ and $17.6 \%$ respectively). The table also shows that the other occupations preferred by Latino women were related to business, finance and administration occupations (26.0\%), with percentages similar to those of the rest of visible minority groups $(25.7 \%)$ and non-visible minority ones (28.8\%). 
Table 1: Occupational Sector Distributions (\%): Latin American, Other Visible Minority and Non-Visible Minority Workers, Canada 2016 *.

\begin{tabular}{|c|c|c|c|}
\hline $\begin{array}{l}\text { NOC } 2016 \text { Occupational Sectors } \\
\text { (1 digit)* }\end{array}$ & $\begin{array}{c}\text { Latin } \\
\text { American }\end{array}$ & $\begin{array}{l}\text { Other } \\
\text { Visible } \\
\text { Minorities }\end{array}$ & $\begin{array}{l}\text { Non -visible } \\
\text { Minority }\end{array}$ \\
\hline \multicolumn{4}{|l|}{ Both Genders } \\
\hline All Occupations & $\begin{array}{r}100.0 \% \\
(n=110.8)\end{array}$ & $\begin{array}{r}100.0 \% \\
(n=1,527.2)\end{array}$ & $\begin{array}{r}100.0 \% \\
(n=6,961.3)\end{array}$ \\
\hline 0 Management occupations & $10.3 \%$ & $12.2 \%$ & $16.0 \%$ \\
\hline 1 Business, finance and administration occupations & $17.6 \%$ & $18.7 \%$ & $18.2 \%$ \\
\hline 2 Natural and applied sciences and related occupations & $11.3 \%$ & $13.1 \%$ & $8.4 \%$ \\
\hline 3 Health occupations & $5.0 \%$ & $7.7 \%$ & $6.1 \%$ \\
\hline 4 Occupations in education, law, and social, community and government services & $9.4 \%$ & $9.7 \%$ & $13.1 \%$ \\
\hline 5 Occupations in art, culture, recreation and sport & $2.0 \%$ & $1.5 \%$ & $2.2 \%$ \\
\hline 6 Sales and service occupations & $21.9 \%$ & $19.5 \%$ & $15.1 \%$ \\
\hline 7 Trades, transport and equipment operators and related occupations & $14.2 \%$ & $10.0 \%$ & $15.1 \%$ \\
\hline 8 Natural resources, agriculture and related production occupations & $0.9 \%$ & $0.5 \%$ & $1.4 \%$ \\
\hline 9 Occupations in manufacturing and utilities & $7.4 \%$ & $7.0 \%$ & $4.4 \%$ \\
\hline \multicolumn{4}{|l|}{ Males } \\
\hline All Occupations & $\begin{array}{r}100.0 \% \\
(n=61.8)\end{array}$ & $\begin{array}{r}100.0 \% \\
(\mathrm{n}=841,6)\end{array}$ & $\begin{array}{r}100.0 \% \\
(n=3,859.2)\end{array}$ \\
\hline 0 Management occupations & $11.1 \%$ & $13.9 \%$ & $18.1 \%$ \\
\hline 1 Business, finance and administration occupations & $10.9 \%$ & $13.0 \%$ & $9.8 \%$ \\
\hline 2 Natural and applied sciences and related occupations & $15.4 \%$ & $18.5 \%$ & $12.0 \%$ \\
\hline 3 Health occupations & $2.2 \%$ & $3.8 \%$ & $2.1 \%$ \\
\hline 4 Occupations in education, law, and social, community and government services & $5.0 \%$ & $6.0 \%$ & $8.7 \%$ \\
\hline 5 Occupations in art, culture, recreation and sport & $2.0 \%$ & $1.5 \%$ & $2.0 \%$ \\
\hline 6 Sales and service occupations & $19.0 \%$ & $\mathbf{1 7 . 8} \%$ & $13.0 \%$ \\
\hline 7 Trades, transport and equipment operators and related occupations & $24.3 \%$ & $17.1 \%$ & $26.0 \%$ \\
\hline 8 Natural resources, agriculture and related production occupations & $1.3 \%$ & $0.6 \%$ & $2.2 \%$ \\
\hline 9 Occupations in manufacturing and utilities & $8.9 \%$ & $7.8 \%$ & $6.2 \%$ \\
\hline \multicolumn{4}{|l|}{ Females } \\
\hline All Occupations & $\begin{array}{r}100.0 \% \\
(n=49.0)\end{array}$ & $\begin{array}{r}100.0 \% \\
(n=685.6)\end{array}$ & $\begin{array}{r}100.0 \% \\
(n=3,102.1)\end{array}$ \\
\hline 0 Management occupations & $9.2 \%$ & $10.1 \%$ & $13.4 \%$ \\
\hline 1 Business, finance and administration occupations & $26.0 \%$ & $25.7 \%$ & $28.8 \%$ \\
\hline 2 Natural and applied sciences and related occupations & $6.0 \%$ & $6.5 \%$ & $3.9 \%$ \\
\hline 3 Health occupations & $8.6 \%$ & $12.5 \%$ & $11.0 \%$ \\
\hline 4 Occupations in education, law, and social, community and government services & $15.1 \%$ & $14.3 \%$ & $18.6 \%$ \\
\hline 5 Occupations in art, culture, recreation and sport & $2.0 \%$ & $1.5 \%$ & $2.4 \%$ \\
\hline 6 Sales and service occupations & $25.5 \%$ & $21.7 \%$ & $17.6 \%$ \\
\hline 7 Trades, transport and equipment operators and related occupations & $1.6 \%$ & $1.4 \%$ & $1.6 \%$ \\
\hline 8 Natural resources, agriculture and related production occupations & $0.4 \%$ & $0.3 \%$ & $0.5 \%$ \\
\hline 9 Occupations in manufacturing and utilities & $5.6 \%$ & $6.0 \%$ & $2.2 \%$ \\
\hline
\end{tabular}

* Note: Full-year, full-time employees aged 25-64, counts (n) in thousands, Source: Census Table 53, Visible

Minority-NOC2016 groups, https://www12.statcan.gc.ca/census-recensement/2016 
4.2. More established immigrant women are more participatory in the Health Sector, recent immigrants in the Sales \& Services sector

Charts 1 and 2 present the participation (in percentages) of Latin American workers in the two occupational sectors by gender, immigrant status and period of residence in the country. With respect to the health sector, the participation of females is higher than that of males regardless of immigrant status and period of residence. Among the Canadian-born Latin Americans, 9.9\% of women had found an occupational niche in this sector compared to men $(2.9 \%)$. The participation in the health sector was found the highest among Latin American foreign-women with 15-24 years period of residence in Canada (11.9\%). With regards to the Sales \& Services sector, overall participation is higher compared to the Health sector one. Canadian-born Latin Americans males and females have almost equal participation rates $(22.7 \%$ and $24.3 \%)$. This latter sector, however, appears more critical in terms of economic survival for recently arrived immigrants (5 years or less in Canada), particularly for females. More than a third of female workers (34.9\%) with a more recent stay were engaged in these type of occupations.

\subsection{Central Americans are among the most participatory in both sectors}

Using an ethnic approximation to the visible minority markers (see Charts 3 and 4), differences in terms of sectoral participation by ethnic origins of workers are apparent. Overall, workers reporting Central American ethnicities displayed higher participation rates than those common in Andean and Southern cone regions of the continent. Workers reporting Hispanic, Nicaraguan and Spanish ethnic origins ${ }^{5}$ displayed the highest rates of participation in the Health sector $(17.6 \%, 15.6 \%$ and $12.5 \%$ respectively). Women were the most engaged in these type of occupations compared to males, with the exception of Salvadoreans where males were found slightly more participatory than females $(11.2 \%$ to 9.6\%). With regards to the Sales \& Services sector, females of Salvadorean, Guatemalan, Costa Rican and Honduran ethnicities were the most participatory in the sector (at least one in three worked in Sales \& Services type of occupations). Again, females were the most engaged in these type of occupations compared to males with the exception of Cubans

5 The 2006 census already revealed that, among those reporting either Hispanic and/or Spanish ethnic origins, about $41 \%$ reported to have been born in Central American countries. 
workers where males were found slightly more participatory than females ( $35.4 \%$ to $30.7 \%)$.

4.4. Female Workers in the Sales \& Services Sector at the bottom of the employment income hierarchy

Median employment incomes calculated for the Latin American workforce indicate that female workers of the Sales \& Services sector are located at bottom levels of the pay hierarchy of the two sectors (see Chart 5). The average median income for these workers is estimated at Can $\$ 30.4 \mathrm{~K}$ while that of their male counterparts at Can\$37.5 K. Chart 5 also shows, that regardless of ethnic origin, with the possible exception of Uruguayans (hovering at an median income of Can\$ $42.0 \mathrm{~K}$ ), female workers of the Sales \& Services sector earned significantly less compared to male counterparts working in the same sector and to greater extent compared to those females working in the Health sector. The lowest median incomes are observed for women reporting Venezuelan, Bolivian and Paraguayan ethnic ancestries with incomes of Can\$26.7K, Can\$25.9K and Can\$24.3K respectively. On the other side of the spectrum, in the Health sector, Argentinian and Venezuelan males (with median incomes of Can $\$ 78.4 \mathrm{~K}$ and $70.0 \mathrm{~K}$ respectively) were found as the most remunerated while Honduran and Ecuadorian as the least (Can\$ 74.3 thousand and 52.3 respectively). 
Chart 1: Participation Rates (in \%) of Latin American Workers in Health Occupations by Immigrant Status and Period of Residence in the country (years), Canada, 2016*.

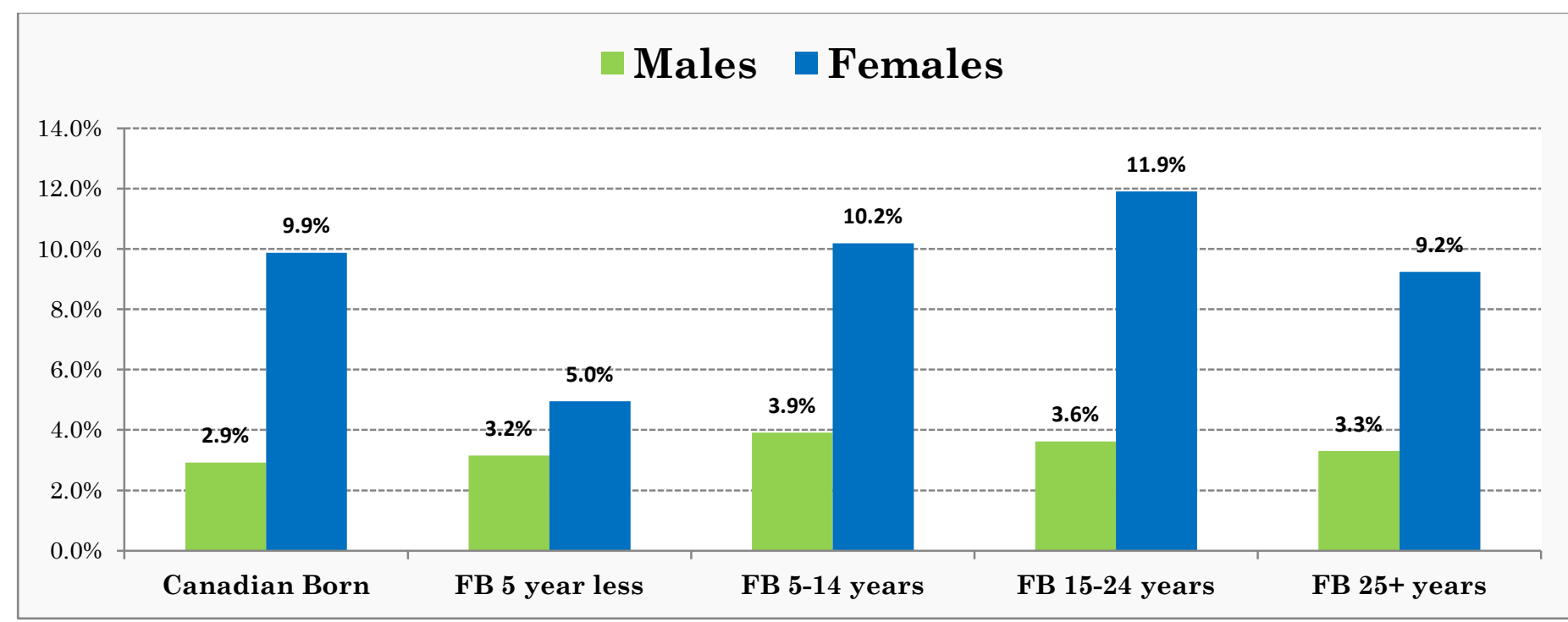

* Note: Full-year, full-time employees, aged 25-64; FB=Foreign-born. Source: Census Table 53, Visible Minority-NOC2016 groups, https://www12.statcan.gc.ca/census-recensement/2016

Chart 2: Participation Rates (in \%) of Latin American Workers in Sales \& Services Occupations by Immigrant Status and Period of Residence in the country (years), Canada, 2016*.

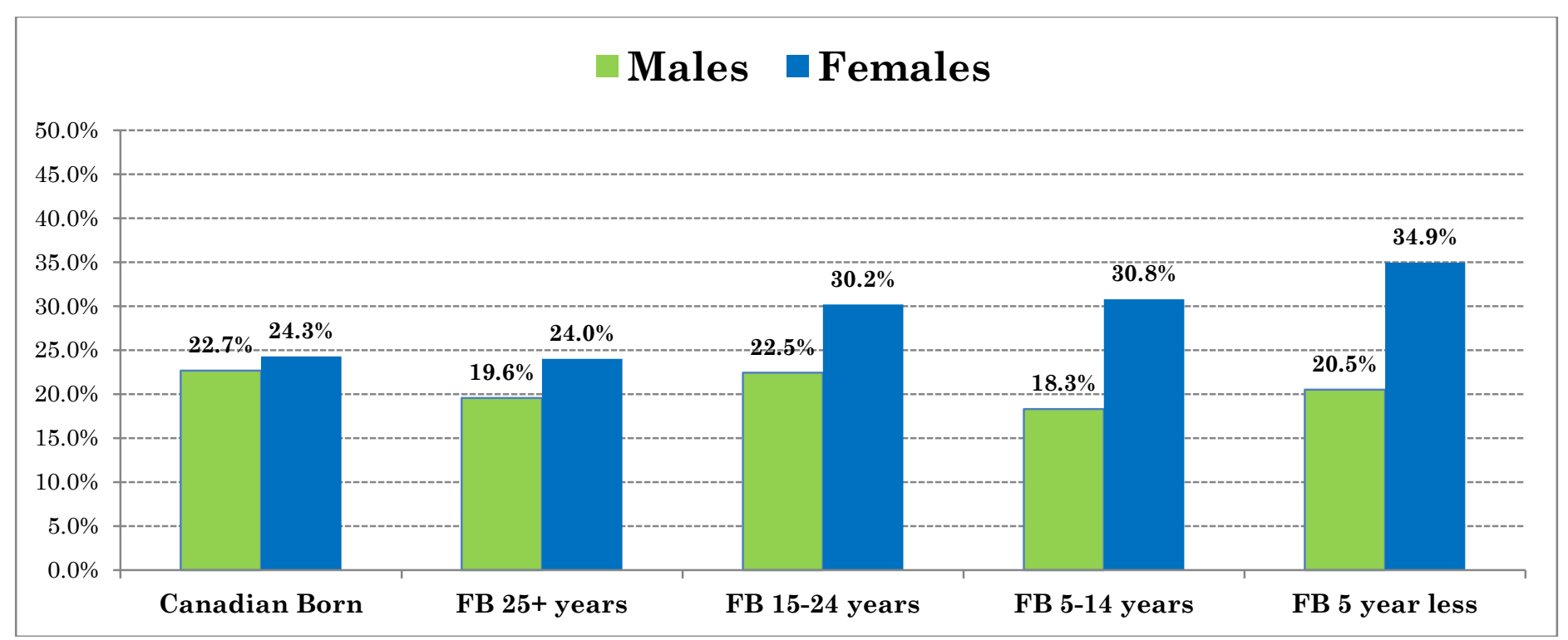

*Note: Full-year, full-time employees, aged 25-64; FB=Foreign-born. Source: Census Table 53, Visible Minority-NOC2016 groups, https://www12.statcan.gc.ca/census-recensement/2016 
Chart 3: Participation Rates (in \%) of Latin American Workers Working in the Health Sector by Ethnic Origins and Gender, Canada, 2016*.

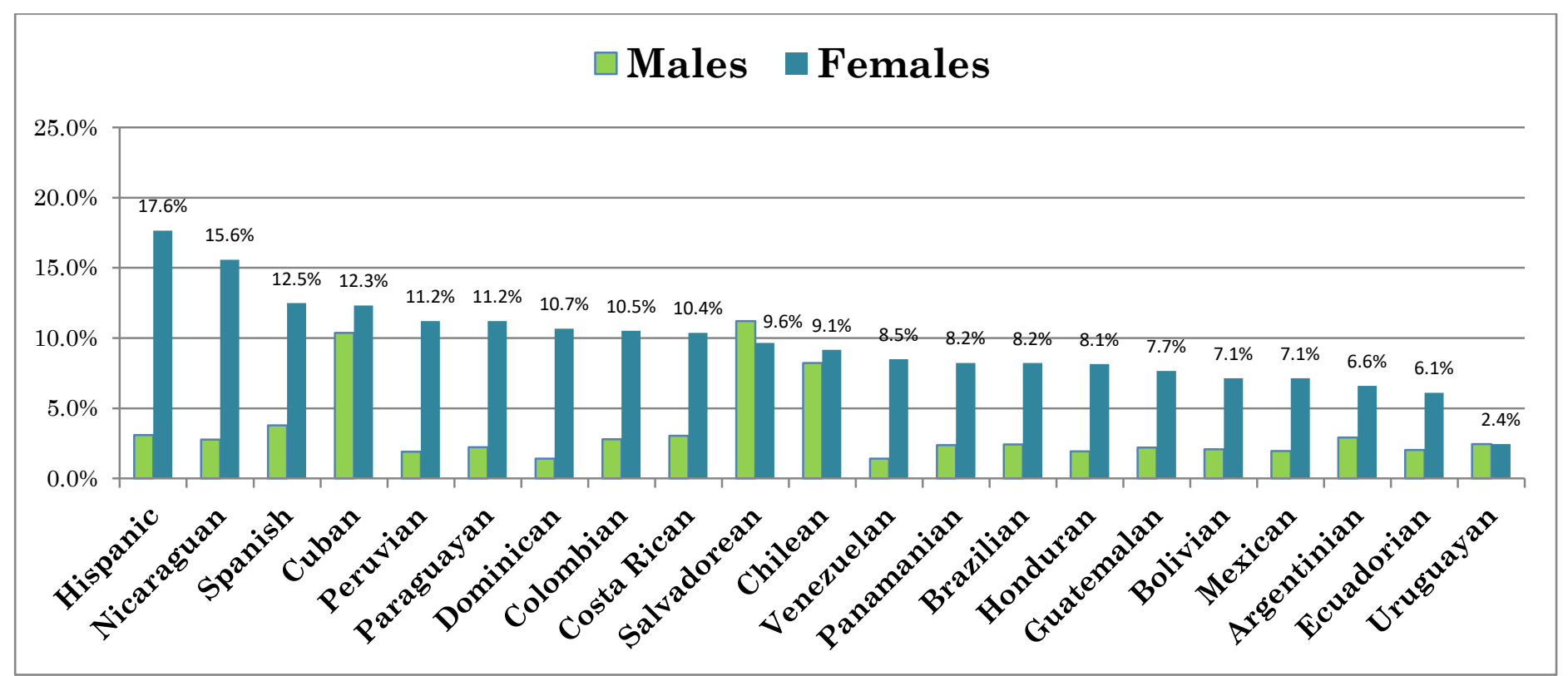

* Note: Full-year, full-time employees, aged 25-64; comprises 360,705 individuals in 21 Ethnic origins; Occupational Distributions based on the 2016 NOC (first digit). Source: Special Table (E03181), 2016 Census of Canada

Chart 4: Participation Rates (in \%) of Latin American Workers Working in the Sales \& Services Sector by Ethnic Origins and Gender, Canada, 2016*

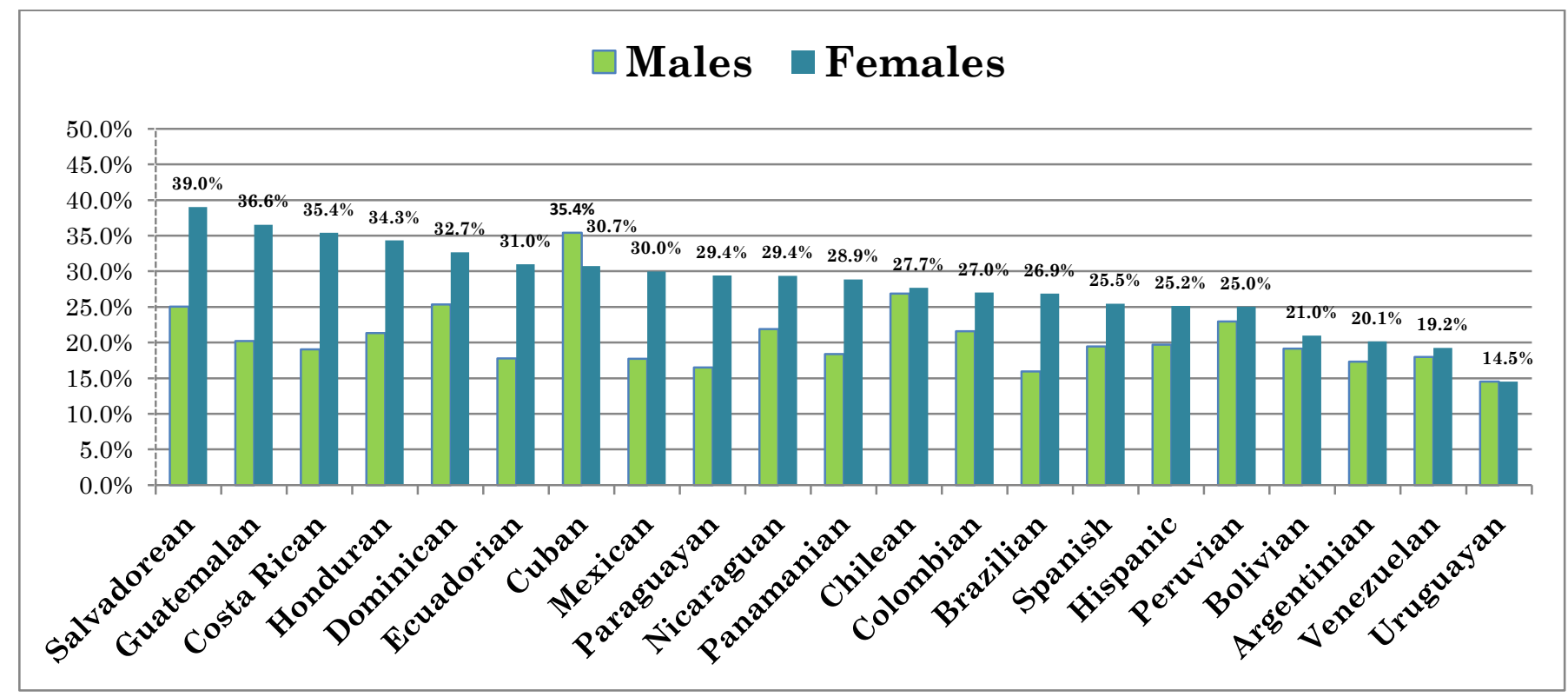

* Note: Full-year, full-time employees, aged 25-64; Comprises 360,705 individuals in 21 Ethnic origins; Occupational Distributions based on the 2016 NOC (first digit). Source: Special Table (E03181), 2016 Census of Canada 
Chart 5: Median Employment Incomes (in thousands) of Latin American and other visible and non-visible minority workers of the Health and Sales \& Services Sectors, Canada 2016*

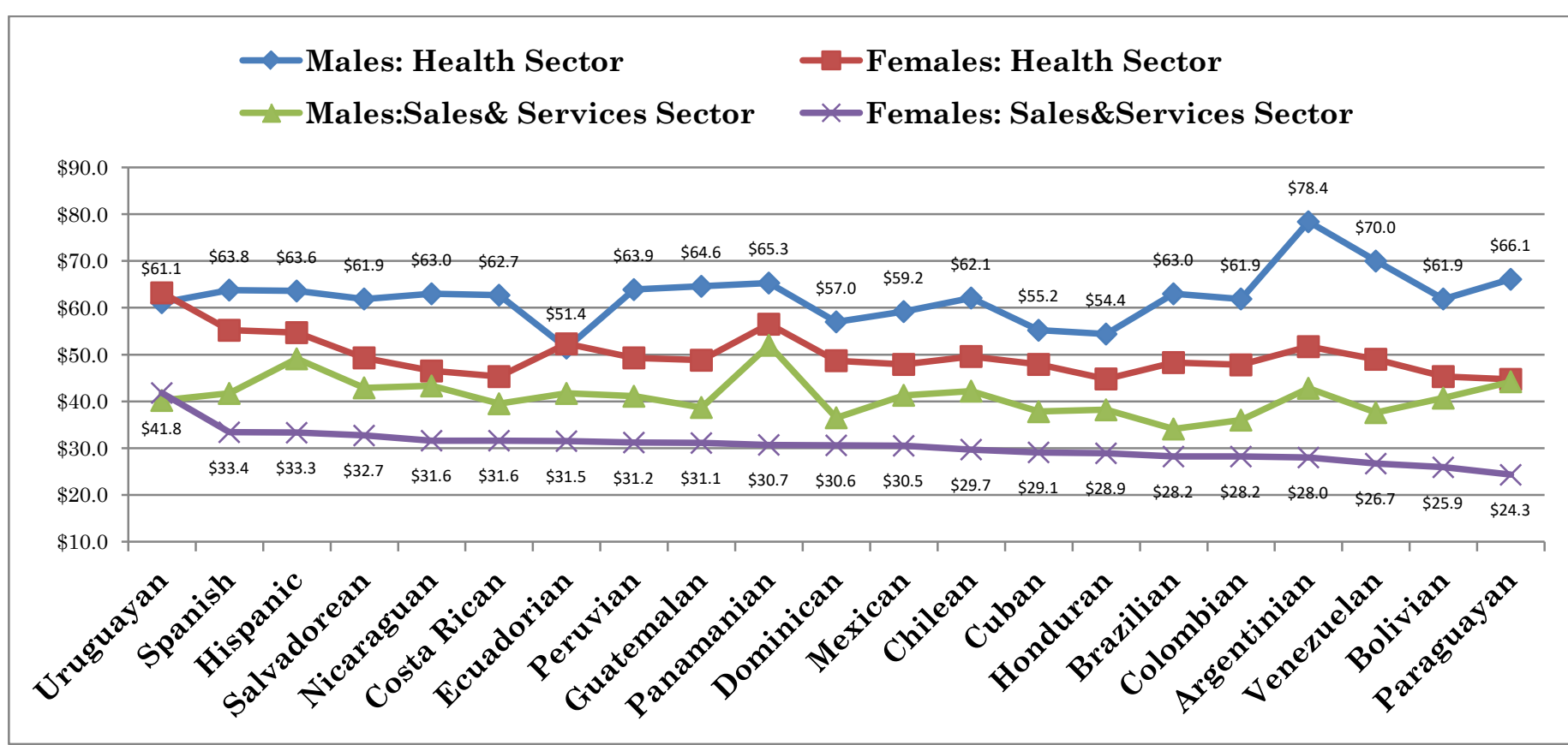

* Note: Full-time, full-year employees, aged 25-64. Source: Census Table 53, Visible Minority-NOC2016 groups, https://www12.statcan.gc.ca/census-recensement/2016

\subsection{Nursing Aides, Janitors and Cleaners: The Most Typical Occupations}

The NOC 2016 occupational system also provided insights into the broad occupational groups $^{6}$ where Latinos tend to be concentrated (see Charts 5 and 6). Half of the male Latin American workforce of the Health Sector do so as nurse aides (50.4\%), the proportion among females is $44.1 \%$. The proportions of registered nurses in the male population is estimated at $8.5 \%$ and that in the female population is almost double at $15.1 \%$. The number of nursing jobs rise if the contingent of female licensed practical nurses is taken into account (6.5\%). With respect to the male workforce in the Sales \& Services sector, two main types of occupations are observed and these account for about a third of workers (janitorial and cleaning related jobs, $18.6 \%$ and $14.8 \%$ respectively). Among females, one in four (23.3\%) work in light duty and specialized cleaning while a further $7.9 \%$ did so in janitorial-related duties. Also common to both groups is the presence of typical activities related to retail sales and food provision and distribution: cashiers, servers and shelvers (8.2\% among males and $9.9 \%$ among females).

${ }^{6}$ The four digit codes of the 2016 NOC were aggregated into single ones for an easier interpretation of typical occupations. 
Chart 6: Job Types of Male and Female Latin American Workers Working in the Health Sector, Canada, 2016*.

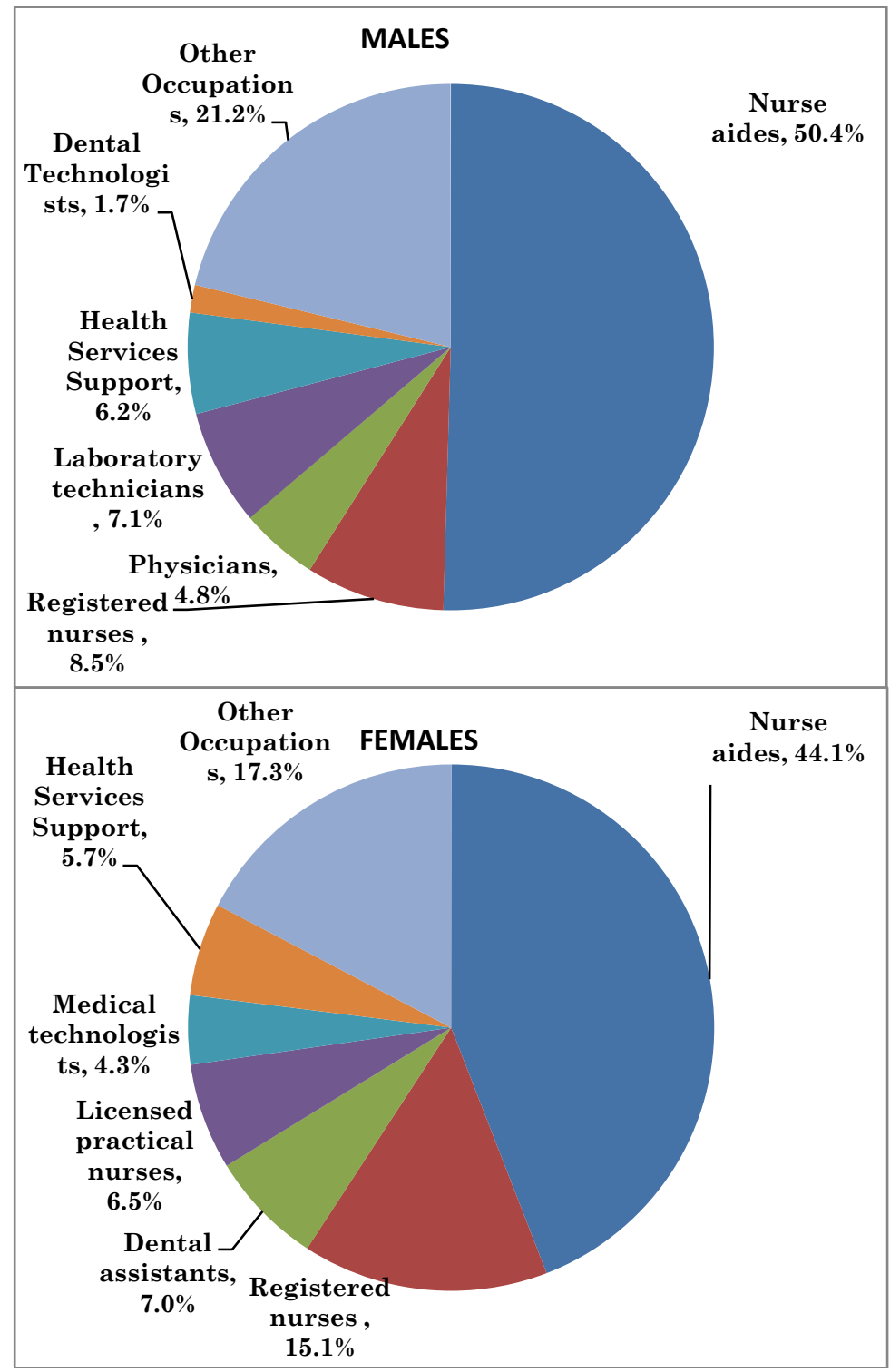

* Note: Full time, full-year employees, aged 25-64. Source: Census Table 53, Visible Minority-NOC2016 groups, https://www12.statcan.gc.ca/census-recensement/2016 
Chart 7: Job Types of Male and Female Latin American Workers Working in the Sales and Service Sector, Canada, 2016*.

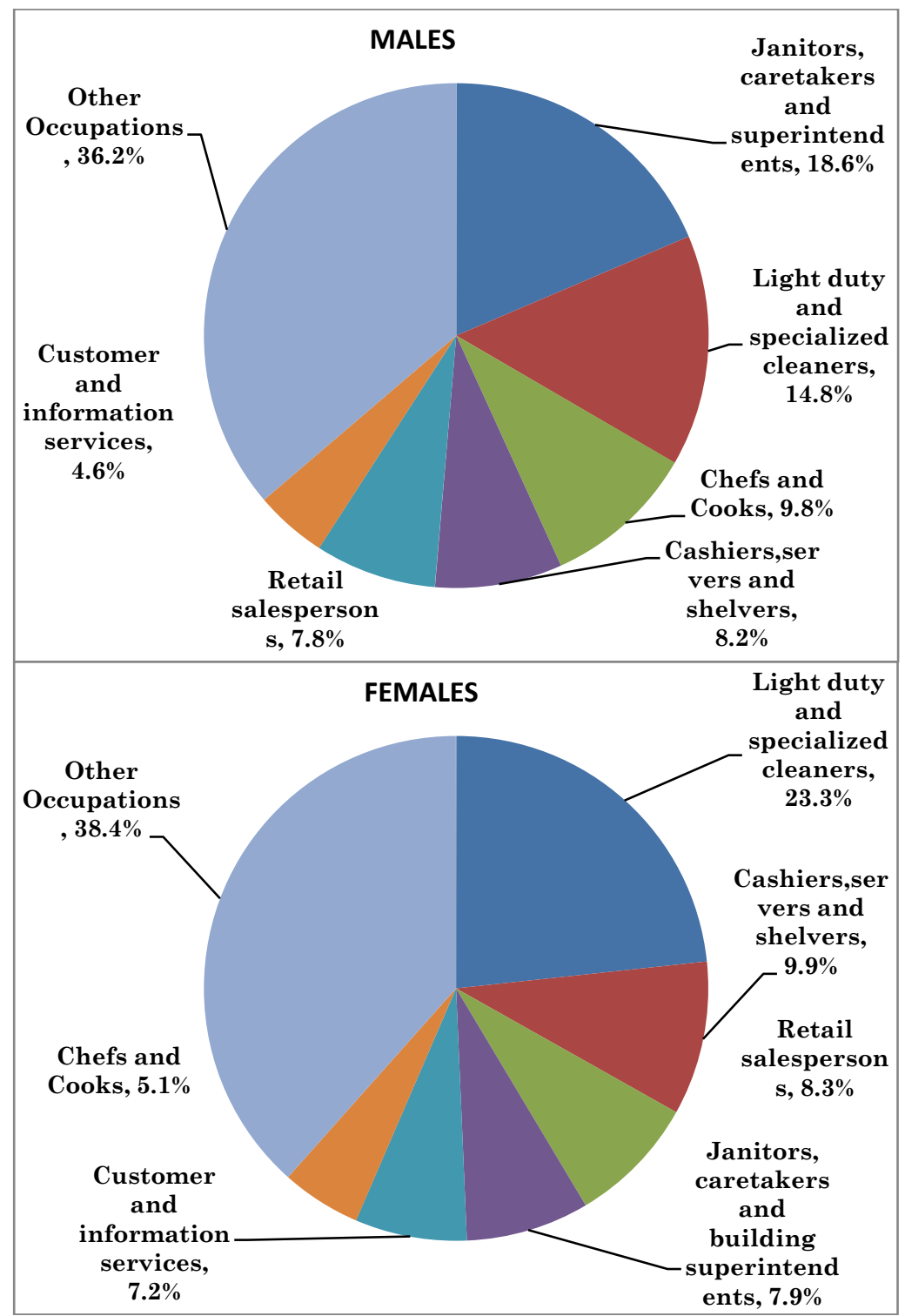

* Note: Full-time, full-year employees, aged 25-64. Source: Census Table 53, Visible Minority-NOC2016 groups, https://www12.statcan.gc.ca/census-recensement/2016.

\subsection{Lower human capital requirements in the most typical occupations within sectors}

Charts 8 and 9 present the educational profiles of the most typical occupations found among Latin American workers of the Health and Sales \& Services sectors. With respect to the nursing aides of the Health sector, holders of no certificates or high schools certificates are a majority among males and females (55.7\% and $47.6 \%$ respectively). Also noticeable are 
the presence of holders of post-secondary degrees holders. One in five of workers $(22.0 \%$ among males and $21.0 \%$ among females) were holders of a trade-equivalent certificate. For those working in light and/or specialized cleanings in the Sales \& Services sector, holders high school certificates or with no educational credentials at all constitute about half of workers (50.2\% among males and 54.2\% among females). Post-secondary educational attainments were also observed here including those holding university-equivalent degrees (below and above bachelor level): $22.4 \%$ among males and $22.8 \%$ among females.

\subsection{Latin Americans share some similar occupational profiles with other visible minorities}

Table 2 provides a comparative outlook on the prevalence of typical occupations within the Health and Sales \& Services sectors across visible and non-visible minority workers engaged in specific economic activities. The table suggests that nursing aides (SOC 2016 code 3413) are not only prevalent among Latin Americans but also among other groups such as Filipinos and Blacks. More than half of male and female workers of these racial backgrounds were engaged in this particular type of occupation. A similar pattern is observed with respect to registered nurses (SOC 2016 code 3012) where the prevalence of Latin American female workers is notably lower than that of their Black counterparts (15.1\% to $26.2 \%)$. Looking at the Sales \& Services sector, the prevalence of janitorial and related jobs (2016 NOC code 6733) among Latin American male workers appeared slightly lower compared to that of Filipino ones (18.6\% to $23.6 \%$ ). The most outstanding finding with respect to the latter sector, however, pertains to the higher prevalence of specific light duty jobs (SOC 2016 code 6731) among Latin American male and female workers compared to other visible minority workers. Among females, this prevalence was higher $(22.7 \%)$ compared to that of Black and Filipino workers (14.2\% and 18.3\% respectively). Among males, similar prevalence $(12.3 \%)$ was slightly higher compared to that of Black and Filipino ones $(7.7 \%$ and $9.3 \%)$. 
Chart 8: Percentage of individuals working as nurse aides by educational level attained and gender, Latin American Workers aged 25-64, Health Sector, Canada, 2016*.

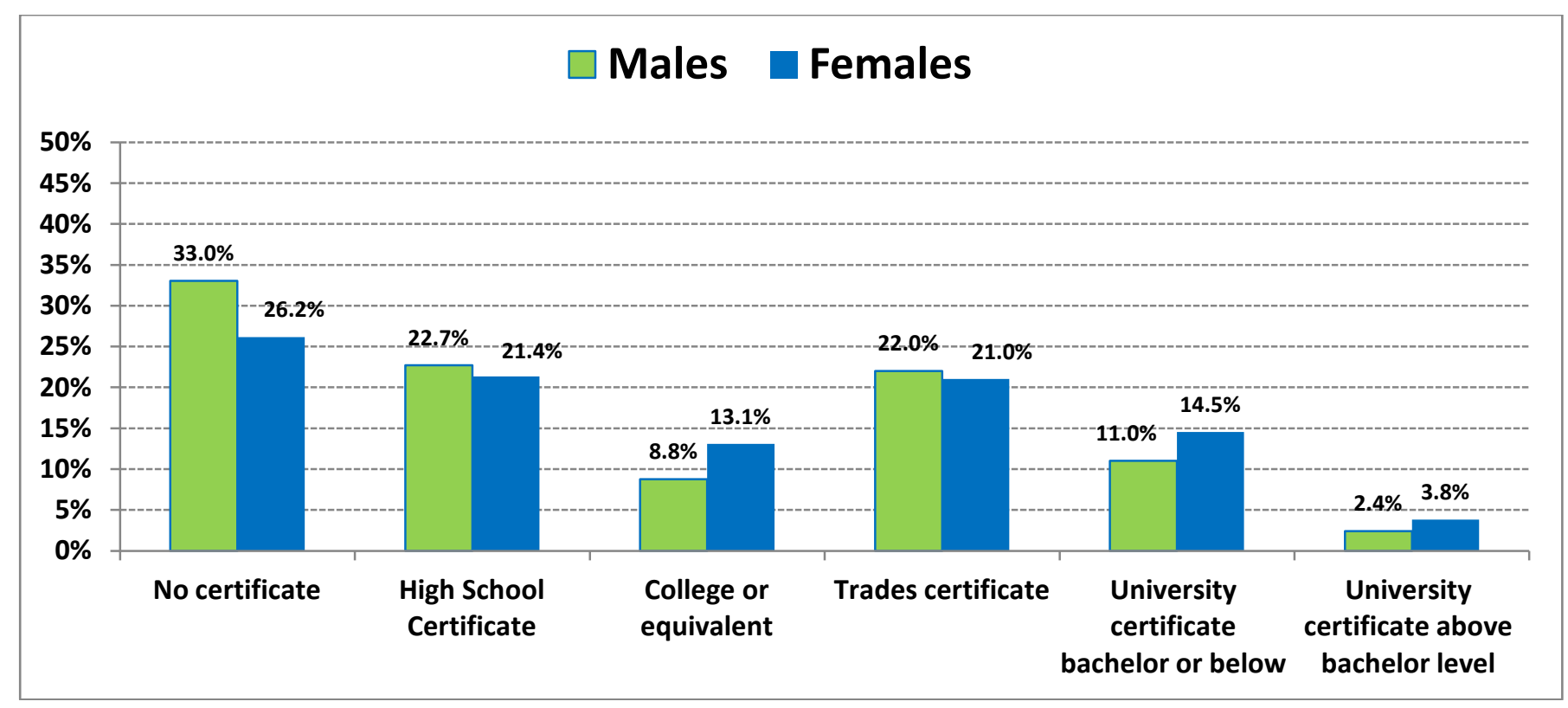

* Note: Full-time, full-year employees, aged 25-64. Source: Census Table 53, Visible Minority-NOC2016 groups, https://www12.statcan.gc.ca/census-recensement/2016

Chart 9: Percentage of individuals working as light or specialized cleaners by educational level attained and gender; Latin American Workers aged 25-64, Sales and Services Sector, Canada, 2016*.

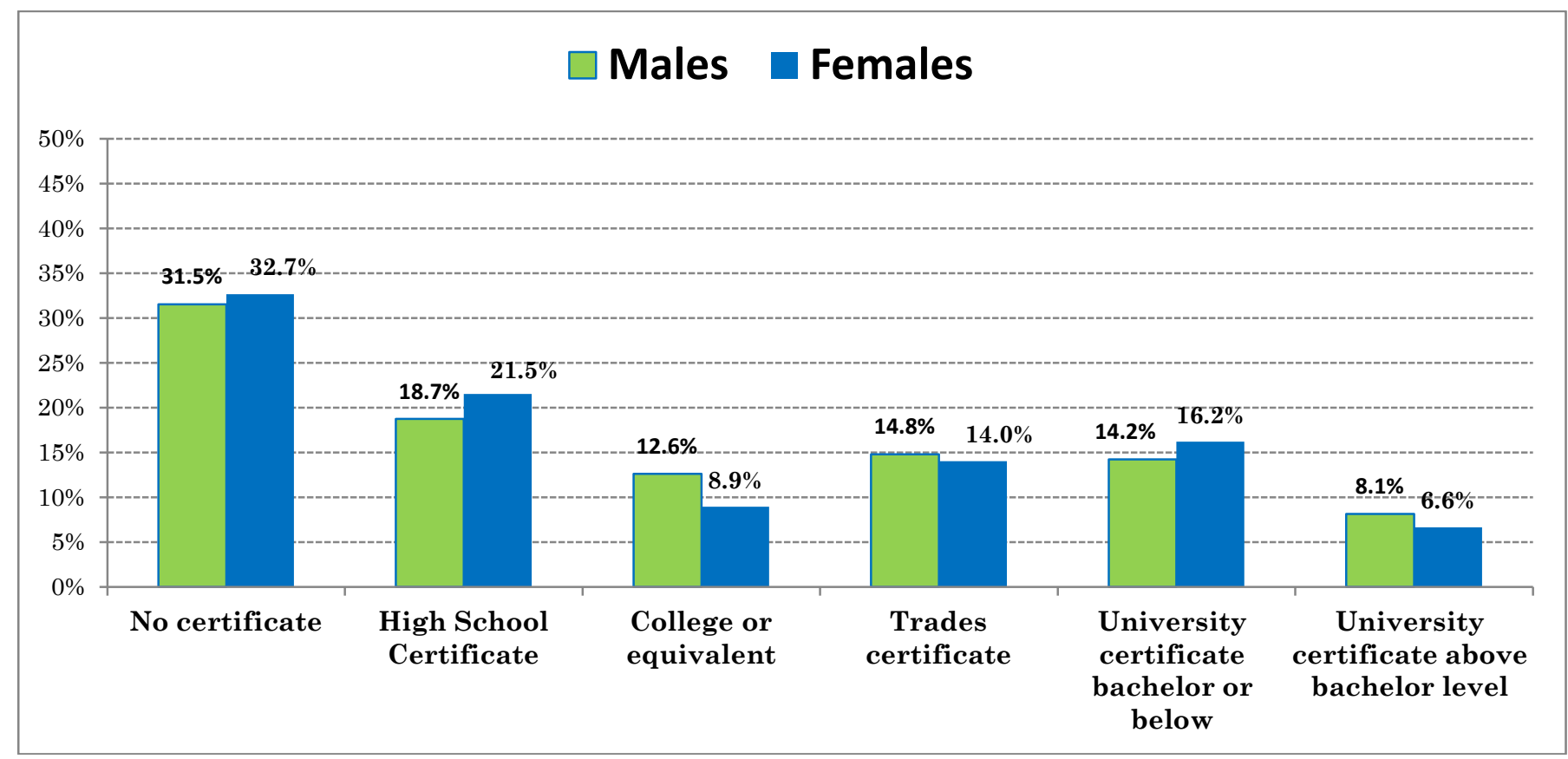

*Note: Full-time, full-year employees, aged 25-64. Source: Census Table 53, Visible Minority-NOC2016 groups, https://www12.statcan.gc.ca/census-recensement/2016 


\subsection{Final Thoughts: The Latin American Workforce in Canada's Pandemic Times}

If 2016 Census figures reflect today's picture, the Latin Americans workforce is actively engaged in the fight against COVID-19 in Canada. The occupational portrait carried out here revealed an active participation of these workers in terms of activities enhancing sanitary protection and economic survival of the Canadian population. In the health front, Latin Americans perform vital roles in terms of nursing support and, in terms of personal services, in sanitary conditions, infrastructure maintenance and food provision \& distribution. Women, established and recent immigrants, as well as Central American workers (many of whom were admitted to Canada as refugees) were found among the most participatory Latino groups in the two occupational sectors examined.

Table 2: Percentage of Workers engaged in Most Typical Jobs within the Health and Sales \& Services sectors by visible minority and non-minority groups and gender, Canada, 2016*.

\begin{tabular}{|c|c|c|c|c|c|c|c|c|c|c|c|}
\hline 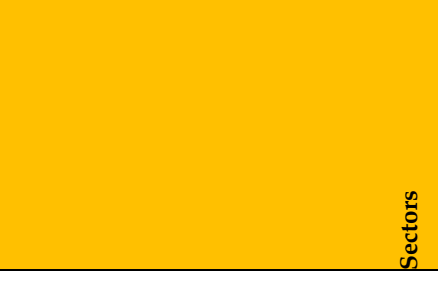 & 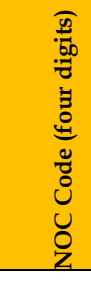 & 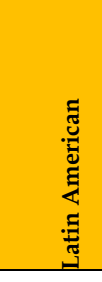 & 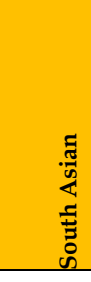 & 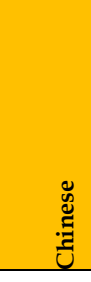 & 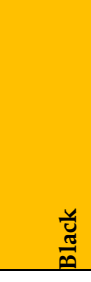 & 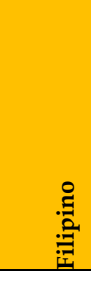 & 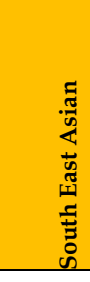 & $\begin{array}{l}\text { ฮ๊ } \\
\stackrel{0}{0 ̆} \\
\underline{v}\end{array}$ & $\begin{array}{l}\frac{5}{5} \\
\frac{\pi}{5} \\
\text { ग } \\
3\end{array}$ & 苋 & 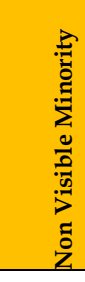 \\
\hline \multicolumn{12}{|l|}{ Health Sector: Males } \\
\hline 1.Nurse aides & $\mathrm{O} 3413$ & $50.4 \%$ & $30.6 \%$ & $16.2 \%$ & $52.1 \%$ & $53.9 \%$ & $25.4 \%$ & $0.0 \%$ & $35.5 \%$ & $18.9 \%$ & $29.9 \%$ \\
\hline 2.Registered nurses & $\mathrm{O} 3012$ & $8.5 \%$ & $6.8 \%$ & $7.5 \%$ & $12.9 \%$ & $13.0 \%$ & $2.7 \%$ & $1.0 \%$ & $2.2 \%$ & $6.2 \%$ & $10.0 \%$ \\
\hline \multicolumn{12}{|l|}{ Health Sector: Females } \\
\hline 1.Nurse aides & $\mathrm{O} 3413$ & $44.1 \%$ & $44.2 \%$ & $29.4 \%$ & $54.1 \%$ & $59.6 \%$ & $31.6 \%$ & $33.4 \%$ & $29.8 \%$ & $34.0 \%$ & $6.6 \%$ \\
\hline 2.Registered nurses & $\mathrm{O} 3012$ & $15.1 \%$ & $20.4 \%$ & $14.4 \%$ & $26.2 \%$ & $14.6 \%$ & $15.8 \%$ & $29.4 \%$ & $10.6 \%$ & $11.9 \%$ & $1.2 \%$ \\
\hline \multicolumn{12}{|l|}{ Sales \& Social Services Sector: Males } \\
\hline 1.Janitors and related & O6733 & $18.6 \%$ & $7.3 \%$ & $4.9 \%$ & $11.2 \%$ & $23.6 \%$ & $9.4 \%$ & $5.0 \%$ & $5.9 \%$ & $5.3 \%$ & $12.1 \%$ \\
\hline 2.Light duty cleaners & O6731 & $12.3 \%$ & $2.9 \%$ & $1.5 \%$ & $7.7 \%$ & $9.3 \%$ & $4.4 \%$ & $2.9 \%$ & $1.2 \%$ & $5.4 \%$ & $3.5 \%$ \\
\hline 3.Retail salespersons & O6421 & $7.8 \%$ & $11.7 \%$ & $11.4 \%$ & $7.9 \%$ & $6.4 \%$ & $6.6 \%$ & $12.0 \%$ & $13.8 \%$ & $11.2 \%$ & $15.3 \%$ \\
\hline 4.Cooks & O6322 & $5.6 \%$ & $9.9 \%$ & $14.4 \%$ & $5.2 \%$ & $8.8 \%$ & $12.8 \%$ & $16.4 \%$ & $9.5 \%$ & $9.7 \%$ & $4.7 \%$ \\
\hline \multicolumn{12}{|c|}{ Sales \& Social Services Sector: Females } \\
\hline 1.Light duty cleaners & O6731 & $22.7 \%$ & $6.5 \%$ & $3.7 \%$ & $14.2 \%$ & $18.3 \%$ & $5.1 \%$ & $3.2 \%$ & $5.3 \%$ & $4.7 \%$ & $1.2 \%$ \\
\hline 2.Retail salespersons & O6421 & $8.3 \%$ & $9.8 \%$ & $10.9 \%$ & $7.3 \%$ & $8.7 \%$ & $6.2 \%$ & $7.2 \%$ & $15.8 \%$ & $11.8 \%$ & $0.7 \%$ \\
\hline 3.Janitors and related & O6733 & $7.9 \%$ & $2.6 \%$ & $1.3 \%$ & $3.3 \%$ & $4.1 \%$ & $2.0 \%$ & $0.8 \%$ & $1.2 \%$ & $1.6 \%$ & $0.7 \%$ \\
\hline 4.Food preparation \& distribution & O6711 & $4.8 \%$ & $11.2 \%$ & $7.5 \%$ & $6.9 \%$ & $15.4 \%$ & $6.3 \%$ & $5.2 \%$ & $5.7 \%$ & $5.0 \%$ & $0.2 \%$ \\
\hline
\end{tabular}

*Note: Full-time, full-year employees, aged 25-64. Source: Census Table 53, Visible Minority-NOC2016 groups, https://www12.statcan.gc.ca/census-recensement/2016 
What are the linkages between the occupational characteristics of Latino workers and the demands that the COVID-19 emergency has placed on the Canadian workforce? Nursing aides help both doctors and registered nurses in taking care of people. Light duty cleaning and janitorial staff are pivotal in cleaning lobbies, hallways, offices and rooms of hotels, motels, resorts, hospitals, factories and schools. In addition, many Latinos are involved in retail sales, the preparation and distribution of food, and warehousing, which are key in terms of the well-being of the population during the pandemic period. Given the nature of their work and in spite of low status, often contractual basis of their work and relative lower rates of pay, Latin Americans carry on with daily duties in close contact with colleagues of strangers, some of which may be potentially COVID-19 "virus-carriers". Many repeat their tasks in prolonged proximity to surface and working quarters.

Seen in a broader context, Latin American workers, like many visible minority and nonvisible minority workers, are shouldering the pressures brought by the COVID-19 emergency by diligently carrying on with their work. The pandemic is creating a series of high health risk "vulnerable" groups in the labour market (see Amarasingue et. al., 2020). Given their work, it is underscores the need to consider additional income supports and providing physical protections for the Latin American workforce and other segments responding to the pandemic. Further avenues of investigation include a focus those who are performing the most risky jobs in terms of disease exposure, proximity to other people, and the total number of people potentially being infected.

\subsection{References}

Amarasinghe, U., Motha-Pollock, A., Felder, M. and Oschinski, M. (2020). COVID-19 and Ontario's Sales and Service Workers: Who is most vulnerable?, Mars Report, retrieved from: https://www.marsdd.com/research-and-insights/covid-19-and-ontarios-sales-and-serviceworkers-who-is-most-vulnerable/

Bernhard, J., Landolt, P., and Goldring, L. (2009). “Transnationalizing families: Canadian immigration policy and the spatial fragmentation of care-giving among Latin American newcomers". International Migration 47, 2: 331. 
Fasani, F. and Mazza, J. (2020). A Vulnerable Workforce: Migrant Workers in the COVID-19 Pandemic, Publications Office of the European Union, Luxembourg, 2020, EUR 30225 EN, ISBN 978-92-76-18958-9, doi:10.2760/316665, JRC120730

Garay, E. (2000). Social economic and demographic profile of the Hispanic community. Toronto: Hispanic Development Council.

IRCC-Immigration, Refugees and Citizenship Canada (2017): Refugee Facts and Figures 2017, Permanent Residents by Countries of Citizenship, Ottawa.

Landlot, P., Bernhard, J.K, and Goldring, L. (2011). “Agenda Setting and Immigrant Politics: The Case of Latin Americans in Toronto." American Behavioral Scientist 55, no. 9 (August 2011): 1235- 1266

Mata, F. (1985). Latin American Immigration to Canada: Some Reflections on the Immigration Statistics. Canadian Journal of Latin American and Caribbean Studies, 10, no. 20 (1985): 27-42.

Mata, F. (2020). Exploring the Ethnic Immigrant Inflows from Latin America to Canada: 19812016, unpublished paper presented to the 2020 REDAN-UNAM conference, Mexico City, May 18-20.

Oliveira, E.M. (2020). Measuring the Latin American population in Canada - why is it important? Retrieved from https://chbalegal.com/blog/measuring-the-latin-americanpopulation-in-canada-why-is-it-important

Statistics Canada, SC ( 2017). Ethnic and cultural origins of Canadians: Portrait of a rich heritage, Census of Population 2016, Catalogue no. 98-200-X2016016 ISBN 978-0-660-20339-3

Statistics Canada (2018). Dictionary, Census of Population, 2016. Ottawa: Ontario, Catalogue no. 98-301-X2016001-ISBN 978-0-660-06678-3

Simmons, A. B. (1993). "Latin American Migration to Canada: New Linkages in the Hemispheric Migration and Refugee Flow System." International Journal 48, no. 2: 282-309.

Veronis, L. (2010): Immigrant Participation in the Transnational Era: Latin Americans' Experiences with Collective Organising in Toronto, Journal of International Migration and Integration 11(2):173-192. 


\section{Appendix A: Four Digit Occupational Codes of the NOC 2016, Health and Sales and Services Sectors, Canada 2016}

Health Sector*: : O3011=Nursing co-ordinators and supervisors, O3012=Registered nurses and registered psychiatric nurses, O3111=Specialist physicians, $\mathrm{O} 3112=$ General practitioners and family physicians, O3113=Dentists, O3114=Veterinarians, O3121=Optometrists, O3122=Chiropractors, O3124=Allied primary health practitioners, O3125=Other professional occupations in health diagnosing and treating, O3131=Pharmacists, O3132=Dietitians and nutritionists, O3141=Audiologists and speech-language pathologists, O3142=Physiotherapists, O3143=Occupational therapists, O3144=Other professional occupations in therapy and assessment O3211=Medical laboratory technologists, O3212=Medical laboratory technicians and pathologists' assistants, O3213=Animal health technologists and veterinary technicians, O3214=Respiratory therapists, clinical perfusionists and cardiopulmonary technologists, O3215=Medical radiation technologists, O3216=Medical sonographers, O3217=Cardiology technologists and electrophysiological diagnostic technologists, n.e.c., O3219=Other medical technologists and technicians (except dental health), O3221=Denturists, O3222=Dental hygienists and dental therapists, O3223=Dental technologists, technicians and laboratory assistants, O3231=Opticians, O3232=Practitioners of natural healing, O3233=Licensed practical nurses, O3234=Paramedical occupations, O3236=Massage therapists, O3237=Other technical occupations in therapy and assessment, O3411=Dental assistants, O3413=Nurse aides, orderlies an d patient service associates, O3414=Other assisting occupations in support of health services. *=Occupations not elsewhere classified

SalesEServices Sector*: O6211=Retail sales supervisors, O6221=Technical sales specialists - wholesale trade, O6222=Retail and wholesale buyers, O6231=Insurance agents and brokers, O6232=Real estate agents and salespersons, O6235=Financial sales representatives, O6311=Food service supervisors, O6312=Executive housekeepers, O6313=Accommodation, travel, tourism and related services supervisors, O6314=Customer and information services supervisors, O6315=Cleaning supervisors, O6316=Other services supervisors, O6321=Chefs, O6322=Cooks, O6331=Butchers, meat cutters and fishmongers - retail and wholesale, O6332=Bakers, O6341=Hairstylists and barbers, O6342=Tailors, dressmakers, furriers and milliners, O6343=Shoe repairers and shoemakers, O6344=Jewellers, jewellery and watch repairers and related occupations, O6345=Upholsterers, O6346=Funeral directors and embalmers, O6411=Sales and account representatives - wholesale trade (non-technical), O6421=Retail salespersons, O6511=Maîtres d'hôtel and hosts/hostesses, O6512=Bartenders, O6513=Food and beverage servers, O6521=Travel counsellors, O6522=Pursers and flight attendants, O6523=Airline ticket and service agents, O6524=Ground and water transport ticket agents, cargo service representatives and related clerks, O6525=Hotel front desk clerks, O6531=Tour and travel guides, O6532=Outdoor sport and recreational guides, O6533=Casino occupations, O6541=Security guards and related security service occupations, O6551=Customer services representatives - financial institutions, O6552=Other customer and information services representatives, O6561=Image, social and other personal consultants, O6562=Estheticians, electrologists and related occupations, O6563=Pet groomers and animal care workers, O6564=Other personal service occupations, O6611=Cashiers, O6621=Service station attendants, O6622=Store shelf stockers, clerks and order fillers, O6623=Other sales related occupations, O6711=Food counter attendants, kitchen helpers and related support occupations, O6721=Support occupations in accommodation, travel and facilities set-up services, O6722=Operators and attendants in amusement, recreation and sport,O6731=Light duty cleaners, O6732=Specialized cleaners, O6733=Janitors, caretakers and building superintendents, O6741=Dry cleaning, laundry and related occupations, O6742=Other service support occupations n.e.c. *=Occupations not elsewhere classified 